\title{
Tendencies in Spatial Planning in Austria
}

\begin{abstract}
K. Hladká
In Austria there is a federal system, where the power is shared between national (Bund) and regional (Land) govermments, with each having autonomy in some spheres, and able to pass laws. Power resides with the national government, although certain responsibilities may be delegated to regional govermments. In Austria the national govermment has no competence in spatial planning, but planning at the national level is undertaken through a joint forum which has advisory powers, and in which the national government and the Länder Austrian are equal partners. At regional level the Austrian Länder play the primary role in spatial planning. The Austrian national government has only limited responsibilities.
\end{abstract}

Keywords: Austria Conference on Regional Planning (ÖROK), Bund, Land/Länder, ÖSTAT (Austrian Central Statistical Office).

\section{Introduction}

With Austrian accession to the EU (1995) and integration into the West European Single Market, changes have also taken place in the institutional framework conditions. The new regional structures in Europe, liberalisation of the reformed Länder, their newly defined political and social orientation, together with the progressive integration of the West European states, are also relevant for the orientation of national spatial planning. The new Europe requires a new political level of action, spatial planning on an European scale.

\section{Spatial planning in Austria}

The terms Raumordnung (space arrangement) and Raumplanung (space planning) are not used in an uniform way in Austria. These terms were developed and have been used differently in each Land. The term Raumplanung (space planning) was established by article No. 118 of the Constitutional act 1929 as a term in local and supralocal planning. The term Raumordnung (space arrangement) is defined as an activity or aim and result of this activity. The aim of Raumordnung (space arrangement) is not only planning of land use but also includes all measures which influence the kind of space development. The term Raumordnung (space arrangement) should be used as a description for the aim of an activity, and the term Raumplanung (space planning) as the result of this activity.

\section{The federal and national levels}

The Federal government does not have the constitutional right to treat spatial planning on the national level as a task of the Bund (federal authorities). That is why, in the narrower sense, there are no binding plans or medium term concepts at the national level. In individual ministries there is sectoral planning with spatial planning aspects.

Planning by the Länder or the communities has to take federal plans into account. Because of the strict division of competences between the territorial administrative authorities, and the lack of any body with competence at the national level, co-ordination between the Federation and the Provinces has been necessary.

\section{The Austrian Development Concept of 1991 [1]}

The Austrian Regional Planning Concept represents planning policy at Land level providing guidance for relevant regional planning measures carried out at federal, Land and local level. This plan serves as a model for the Bund, the Länder and communities. This plan provides recommendations, and is primarily a set of guidelines for the administration, but also serves as a source of information for members of the public interested in spatial development.

Section I

- deals with the changed conditions for Austrian spatial planning and regional development

Section II

- the economical use of space and the environment

- regional development policy

Section III

- deals with major spatial problem areas in selected sectors and proposes concrete goals and intensification of protective measures

- the setting of limits on areas developed for tourism

- promotion of appropriate agriculture and forestry close to nature

- the introduction of environmental impact assessments

Section IV

- summary of all short-term measures that can be started or implemented to implement the concept quickly

\section{The land level}

The Länder have enacted spatial planning legislation. In general, these laws contain no specific regional plans, but define the goals of such planning. In formal terms, the Land laws determine the planning instruments of each Land and, in much greater detail, the obligations of the communities to carry out local planning.

The level of planning relating to the regions is covered by the Land in question, since there is no territorial administrative authority at this level, and hence no political interest in institutional form. 


\section{State Development Plans}

The plans envisaged in spatial planning laws for the entire territory of a Land are comprehensive in content and are issued by the governments of the Länder as official decrees. These are binding for the authorities themselves in implementing sectoral and regional planning, for carrying out their supervisory functions over the municipalities, and finally also for the local spatial planning activities of the municipalities. The validity of the Development Plans of the Länder is not limited. The plan defines in part the regions for regional planning as well as the subject fields for the sectoral plans, and lay down the minimum content requirements.

\section{Regional Development Plans}

Regional Development Plans are set up in the form of decrees issued by the governments of the Länder. They are binding for spatial planning on local level municipalities. These plans are not limited in duration. Regional Development Plans usually contain goals in several sectors for a region. These are general goals depending on the Land and on the plan, but may sometimes be formulated quite specifically. Responsibility for Regional Development Plans lies with the spatial planning departments of the governments of the Länder. According to their content or level of detail, they represent guidance or limitations on local authority planning. The regional spatial development plans also cover specific measures. Mostly areas of suitability are identified, for agriculture, tourism or industrial use. The degree of detail can be seen from the scale, which ranges from 1:25000 to 1:200 000 .

\section{Sector Planning of the Länder}

This plan deals with spatial planning measures in a limited sector. As decrees, these are binding on the administration of the Land and municipality. As government resolutions they are only binding on the administration of the Land. Sectoral plans are usually only valid for a certain period of time.

\section{The communal level}

All the communal level spatial planning covers the whole area administred by communities. The communities have a legal obligation to engage in spatial planning, and are subject to control by the supervising authority of the government of the Land. Given strong finance, which is the case with many communities, there is considerable scope for an independently determined policy for spatial development at the communal level.

Communities are independent territorial authorities with the right of self-administration. Local planning is a major part of their area of independent action. With responsibility for land use and building plans, the communities play a key role in the overall planning system. The land use plan admittedly has to be approved by the Government of the Land, but approval may only be denied if it conflicts with the Spatial Planning Act or with the supralocal regional development programmes of the Land.

The Spatial Planning Acts of the Länder oblige the communities to employ three planning instruments:

- the spatial development concept

- land use plans

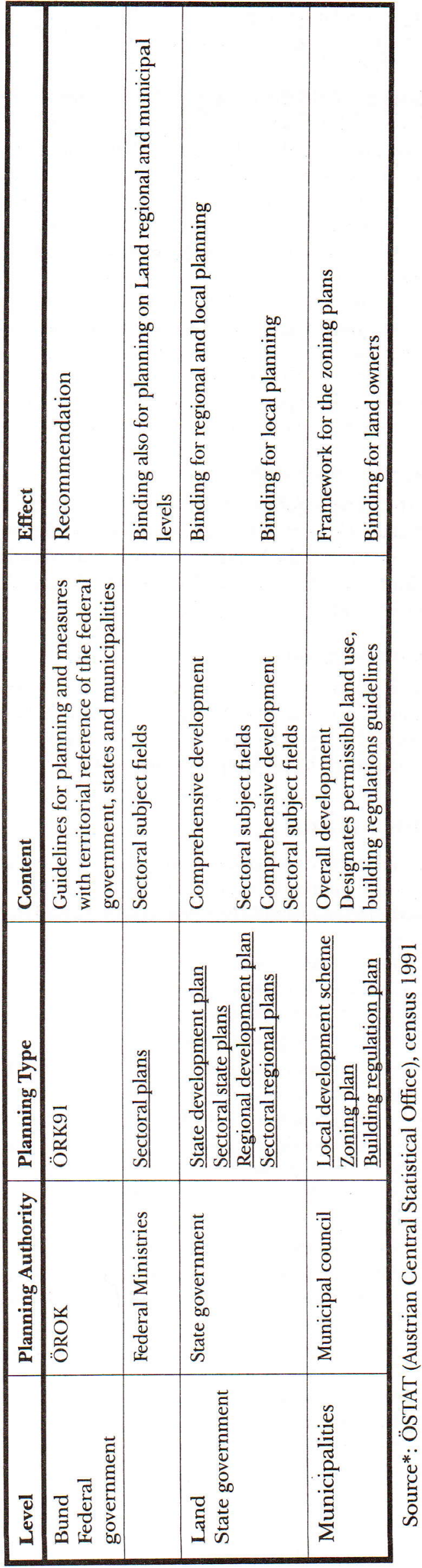


- building regulation plans

\section{Land use plan}

This plan is drawn up for the entire territory of the community and divides it into various categories, i.e. building plots, green land, traffic areas. The land use plan is binding on site owners, but there is no obligation actually to implement the provisions. The State Government acts as the supervisory authority and approves the land use plan. This must be in accordance with the goals of the spatial planning programme and supralocal spatial planning of the Land, corresponding to the spatial development scheme, and may have to take planning at the federal level into account. The population has to be informed within a given period of time about the intention to draw up a land use plan, and the plan must be available for public inspection before it is finalised, so that everyone has an opportunity to express an opinion.

\section{Building regulation plan}

The building regulation plan is subsidiary to the land use plan. It takes the form of regulations passed by the municipal council, binding on the building authorities and landowners. The minimum content is laid down in the Spatial Planning Acts of the Länder.

\section{Spatial planning laws}

Spatial planning laws are promulgated by the state government of the Land as the legislative body of the Länder. In recent years there have been extensive changes in nearly all Länder, triggered by Austrian accession to the EU.

\section{Conclusion}

The instruments of spatial planning in Austria are determined in the Spatial Planning Acts of the Länder. Thereby a distinction must be made between instruments of supralocal spatial planning, relating to the entire Land or parts of it, and drawn up by the Governments of the Länder, and those instruments relating to local spatial planning, which refer to a community and which are drawn up by the local authorities with respect to their area of competence.

The laws oblige the Länder to set up Land development programmes for the Land, regional programmes and sectoral development programmes. The terminology used in the various Länder differs according to the local authorities, that are responsible for local spatial planning.

The Land development programmes of the Länder represent a higher level for the regional development and sectoral development programmes. They define, to an extent, the regions for regional planning, and the subjects covered in sectoral development, determining their minimum content. The Land development plans of the Länder are thus mostly a mixture of the concrete goals, spatial plans and general directives of the Länder for further planning.

\section{References}

[1] Österreichisches Raumordnungskonzept 1991. ÖROK, 1992.

[2] ÖSTAT Austrian Central Statistical Office. ÖSTAT, 1991.
Ing. Kateřina Hladká

email: katerina.hladka@centrum.cz

Na Cihelně 1331

28201 Český Brod, Czech Republic 